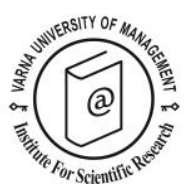

\title{
Owsianowska, S. and Banaszkiewicz, M. (Eds.) (2018) Anthropology of Tourism in Central and Eastern Europe: Bridging Worlds. New York \& London: Lexington Books. Hardback. 334 pages. ISBN 978-1-4985-4381-1
}

\author{
Reviewed by Sagar Singh ${ }^{1 *}$
}

Received: 31/08/2018

${ }^{1}$ Centre for Tourism Research \& Development, India; email: sagar_66@hotmail.com

* Corresponding author

(C) 2019 Varna University of Management. All rights reserved

Citation: Owsianowska, S. and Banaszkiewicz, M. (Eds.) (2018) Anthropology of Tourism in Central and Eastern Europe: Bridging Worlds. New York \& London: Lexington Books. Hardback. 334 pages. ISBN 978-1-4985-4381-1. Reviewed by Sagar Singh, European Journal of Tourism Research 21, pp. 153-154

The book delivers what it promises, in term of describing and analyzing the bridges between the worlds of 'world anthropology' (a 'strongly networked academic club to which admission of outsiders [was] rare' in Nelson Graburn's terms, p. 36), from which Eastern Europe and most regions other than UK, USA, Canada, Hong Kong, Australia, New Zealand were, till recently, excluded, and European anthropology. While derived from a conference in Kraków in June 2015, the book is very comprehensive in its coverage and by no means limited to Europe in the scope of fields (where fieldwork is done) referred to. Thus, to the delight of this reviewer, there is one full chapter devoted to India. It is worth mentioning here the distinction between social-cultural anthropology as it is understood in UK and USA, and East European 'ethnology' as a similar branch of the wider Anthropology. One notable difference in the fieldwork tradition one prolonged period in 'social anthropology' versus many, short terms in European ethnology - is pertinent to both social anthropology and most tourism studies with an anthropological hue.

The book is divided into three sections. After the Introduction by the editors, the first section deals with an introduction by Graburn that discusses how it feels to be divided between two different worlds of anthropologists (if not anthropology), termed 'inside and outside the Anglophone snake'. It becomes apparent that not all sub-sections of the anthropology of tourism and travel, as conceived by Graburn, namely, (a) sociocultural impact studies; tourism in relation to (b) ritual and experience; (c) gender; (d) heritage; (e) photography and media; (f) tour guides and tourism imaginaries; and (g) disciplinarity, are equally or evenly represented in the book. Indeed, these subjects are so divided that they are not equally represented even in a possible 'world anthropology of tourism'.

Reading the book is both instructive and impelling: the latter in the direction of a world 
Owsianowska, S. and Banaszkiewicz, M. (Eds.) (2018) Anthropology of Tourism in Central and Eastern Europe: Bridging Worlds. New York \& London: Lexington Books. Hardback. 334 pages. ISBN 978-1-4985-4381-1. Reviewed by Sagar Singh, European Journal of Tourism Research 21, pp. 153-154

that was transformed many times, first by the revolutions, many of which changed the way people were governed, including in such personal areas as religion; and later by the dissolution of communist ideology governing states that let them revert to religious practices and worldviews that were more truly their own. As the editors note in the Introduction, the second part of the book 'focuses on describing the peculiarity of the anthropology of tourism in the broader context of tourism studies'. As ethnography in Eastern Europe or, more particularly, Russia, is intimately tied to historiography, this section of the book makes it more ethno-historical in nature (e.g., the contribution by Maarja Kaaristo) and more reflexive. Most of these studies concentrate on the anthropology of tourism in this region in the past 26 years.

The study by Anna Wieczorkiewicz analyzes the nature of travel by investigating the role maps play in the travel experience. While Maria Zowisło concentrates on the tradition of philosophical reflection in travel, Banaszkiewicz examines the trends in Russian tourism, especially the tension between domestic tourism and outbound tourism, which latter was sometimes perceived as a threat to the political order.

Part III of the book is in eight chapters and consists of contributions in the anthropology of tourism, in regions both inside and outside Central and Eastern Europe. This includes contributions on 'alcotourism' in Bulgaria (Carla Bethmann); power relations between residents, elites and tourists in Hampi, south India, and tourists and resident Tibetans in exile in Dharamshala, Himachal Pradesh (Natalia Bloch); sensual experiences, and cuisine tourism in Russia (Agata Bachórz); and tourism development and the creative industry of lacemaking in Poland (Anna Sznajder and Katarzyna Kosmala), as an example of creative tourism. Armin Mikos, in Chapter 12, shows how professional city guides interpret heritage of some cities in Europe, which, as he shows, is mediated and inter-subjectively constructed. Similarly concentrating on urban complexes, Małgorzata Nieszczerzewska analyzes 'interior tourism' in the context of abandoned places.
Michael Zinganel, in Chapter 14 examines abandoned places in a slightly different way: concentrating on spectacular monuments of the socialist and modernist period in former Yugoslavia, and shows how these illustrate a yearning to revisit, re-appropriate and reevaluate these politically highly contested ruins of an era that is no more.

Chapter 15, by Małgorzata Radkiewicz, is interestingly written and is appropriately titled, 'The "Kodak Girl" on a Trip' and examines tourist (middle class) women from Polish Galicia through photographs taken from the 1910s till the 1930s. The chapter evokes much nostalgia in the minds of those who were born before and after the First World War, when black and white photos were taken, and when Kodak was a measure of quality in photography. It concludes with a note on how 'traveling women, for whom a trip often became an opportunity to exceed the obligatory discipline', used to travel for the sake of not belonging to a structured order, based on binary opposites like masculine/feminine, public/private, social vs. domestic. The photographs 'indicate that they were aware of this freedom', the traces of which can be seen in the compositions and themes of shots made by the 'Kodak Girls' who took those photographs.

The book is a wonderful introduction to an area of tourism and anthropological studies that most anthropologists (both 'in the snake' USA, UK, Australia, New Zealand - and outside it, as in Asia (India, Japan)) do not get a taste of, given the problems of lack of journals and books dedicated to this field, and (self-critically) the insular nature of anthropological studies in Asia, at least in India. The flavor of the book is enhanced by contributions by Nelson Graburn and Tom Selwyn, who provide a perspective from a distance, which, of course, is in the nature of reflexivity. A must-read book for all tourism scholars and students, as well as anthropologists and sociologists. 